\title{
IMMUNOHISTOCHEMISTRY IN DIAGNOSIS OF EXTRANASOPHARYNGEAL ANGIOFIBROMA ORIGINATING FROM NASAL CAVITY: CASE PRESENTATION AND REVIEW OF THE LITERATURE*
}

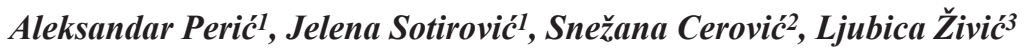

Department of Otorhinolaryngology, Rhinology Unit, Faculty of Medicine, Military Medical Academy, Belgrade, Serbia ${ }^{1}$; Institute of Pathology, Faculty of Medicine, Military Medical Academy, Belgrade, Serbia ${ }^{2}$; Department of Otorhinolaryngology, Faculty of Medical Sciences, Kragujevac, Serbia ${ }^{3}$

Summary: Angiofibromas are rare vascular tumors which originate predominantly in the nasopharynx and occur typically in male adolescents. Extranasopharyngeal sites such as nasal cavity and paranasal sinuses are less frequent. This review article was undertaken to evaluate the incidence, clinical features and management of extranasopharyngeal angiofibromas originating exclusivelly from nasal cavity structures. Our focus of interest was to evaluate the significance of immunohistochemical analysis in diagnosis of such extremely rare neoplasms. In the PubMed and Google Search, we found only 39 cases of nasal angifibroma, 27 males and 12 females from 1980 to 2012. The most prevalent site of origin was nasal septum, followed by inferior and middle turbinate. The commonest symptoms were nasal obstruction and epistaxis. Nasal angiofibromas are clinically distinct from nasopharyneal angiofibromas and can therefore be misdiagnosed. The differential diagnosis includes other vascular lesions, such as lobular capillary hemangioma and sinonasal-type hemangiopericytoma. Although immunohistochemistry is not necessary for differentiation between angiofibroma and capillary hemangioma, that diagnostic procedure may be helpful in distinction from sinonasal hemangiopericytoma. As an ilustration for immunohistochemical analysis, we presented a case of an elderly woman with tumor arising from the middle turbinate, diagnosed as angiofibroma. The staining was positive for CD34, CD31, factor VIII, vimentin and smooth muscle $\alpha$-actin, and negative for desmin.
\end{abstract}

Keywords: Extranasopharyngeal angiofibroma; Nasal cavity; Pathohistological analysis; Immunohistochemistry

\section{Introduction}

According to the predominant opinions, angiofibroma is histologically benign, but locally aggressive vascular tumor, originating from the nasopharynx, near by the area of sphenopalatine foramen. Current evidence indicates that angiofibroma does not originate in the nasopharynx, as has long been assumed, but rather from a fibrovascular nidus in the posterolateral wall of the nasal cavity in the vicinity of the sphenopalatine foramen (1). It represents $0.05 \%$ of all head and neck neoplasms (1). Recent studies show genetic changes to be involved in the origin of angiofibromas (1). This theory is sustained by findings of chromosome 17 delections, including regions of the supressor gen p53 and the oncogen Her-2/neu (2). Others beleive angiofibroma to be a vascular malformation in the sense of non-resorption of a primitive artery of the first branchial arch with the presence of non-chromaphinic paraganglionic cells $(3,4)$. This tumor affects almost solely adolescent males. The incidence in other age groups, in women, and in other primary locations is extremely small. Reports of primary extranasopharyngeal angiofibromas, especially those originating in the nasal cavity structures have appeared exceptionally in the literature. The aim of this review article was to evaluate the incidence, location, clinical characteristics, diagnosis, and management of angiofibroma originating from nasal cavity structures. The focus of our interest was to assess the importance of immunohistochemical analysis in differential diagnosis of these lesions. As an ilustration, we presented a case of an angiofibroma arising from the middle turbinate in a 63-year-old woman. The diagnosis of this tumor is confirmed by precise histopathological and immunohistochemical analysis.

\footnotetext{
* The part of this manuscript was presented and awarded at the 1st Congress of Confederation of European Otorhinolaryngology Head and Neck Surgery (CE-ORL-HNS), July 2-6, 2011, Barcelona, Spain.
} 


\section{Methods}

In a PubMed and Google search, we reviewed the case presentations of extranasopharyngeal angiofibroma arising from the nasal cavity structures throughout the entire medical literature, published from 1980 to 2012. A review of the literature not only in English language was performed.

\section{Results}

We found a total of 39 patients with nasal angiofibroma: 27 males $(69.23 \%)$ and 12 females $(30.76 \%)$. The mean age was 36.10 years. The oldest patient being 78 years old, and the youngest one being 8 years of age. The most commonly afected site of origin were the nasal septum $(n=22$ or $56.41 \%)$ and the inferior turbinate $(\mathrm{n}=9$ or $23.07 \%)$. The less frequently affected nasal cavity structures were lateral nasal wall $(\mathrm{n}=4$ or $10.25 \%)$, middle turbinate $(\mathrm{n}=3$ or $7.69 \%$ ), and nasal vault ( $\mathrm{n}=1$ or $2.56 \%$ ). The commonest symptoms were nasal obstruction ( $\mathrm{n}=33$ or $89.48 \%$ ), epistaxis ( $n=29$ or $79.48 \%$ ), and progressive swelling of the nose $(\mathrm{n}=2$ or $5.12 \%)$. The mean duration of symptoms before the first ENT examination was 4.65 monts. The symptom duration was not precized in three subjects used explanations such as "weeks", "months" or "years".

All patients had primary tumors and twenty-nine underwent endonasal surgical approach. Ten patients with extensive lesions were treated by open, radical surgical approach. Histopathological examination of postoperative samples (haematoxylin-eosin stain) was performed in all patients and showed many irregular blood vessels range from capillaries and sinusoids to large vessels, often with a stellate or "staghorn" appearance, lined with one layer of flat endothelial cells lying in a fibrous stroma.

In only 13 cases $(33.33 \%)$, presented data showed the diagnosis of nasal angiofibroma was confirmed by immunohistochemical analysis. From case to case, the avidin-biotin peroxidase technique was performed for CD34, CD31, CD117, factor VIII, factor XIIIa, vimentin, desmin, $\alpha$-smooth muscle actin, and $\beta$-catenin. No evidence of tumor recurrence was found after surgical excision. All cases of nasal angiofibroma reported in the world literature, including the data regarding treatment approaches and immunohistochemical analyses were presented in the Table 1.

\section{Case presentation}

A 63-year-old woman consulted the Department of Otorhinolaryngology, complaining of an eight month history of progressive left-sided nasal obstruction, facial pain and intemittent epistaxis. Several days before ENT examination, she had few episodes of intensive left-sided nasal bleeding. Except the arterial hypertension, the patient had no other health problems. She had two normal pregnancies and during the beginning of the symptoms, she was in menopause for a long time. The patient did not have any history of bleeding disorders. The coagulation status was normal. On anterior rhinoscopy, a purple, lobular mass was seen through the left nostril, adhering to the anteroinferior portion of the left middle turbinate and occupying the left middle meatus. There was no tumor extending in the nasopharynx on posterior rhinoscopy. Computed tomography (CT) scan of the paranasal sinuses showed a mild contrast enhancing mass that filled the left-sided middle meatus and anterior part of the nasal cavity, total opacity of the left maxillary and ethmoid and partial opacity of the right

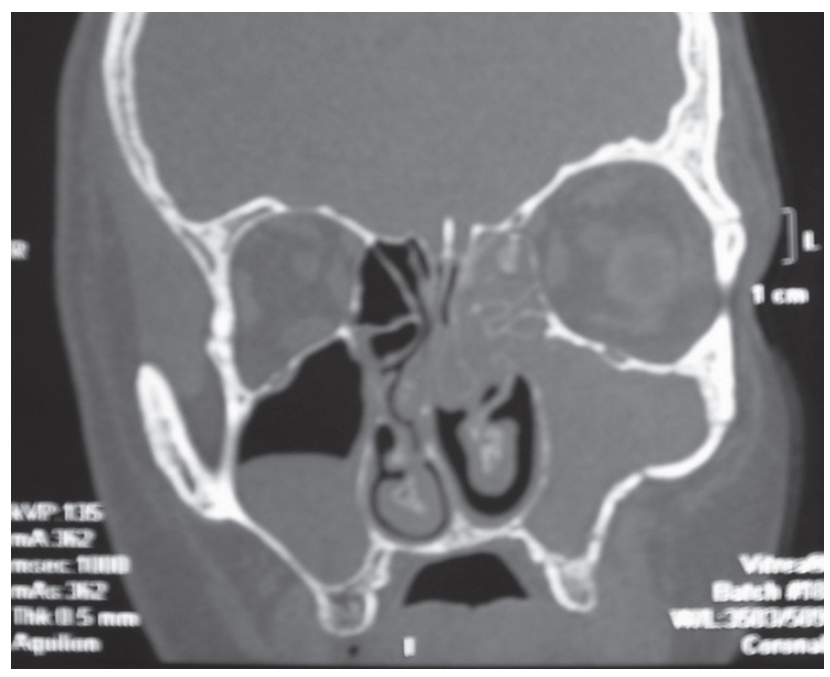

Fig. 1: Coronal CT scan of the nose and paranasal sinuses showed a soft-tissue mass that filled the left-sided middle meatus, with total opacity of the left maxillary and ethmoid and partial opacity of the right maxillary sinus.

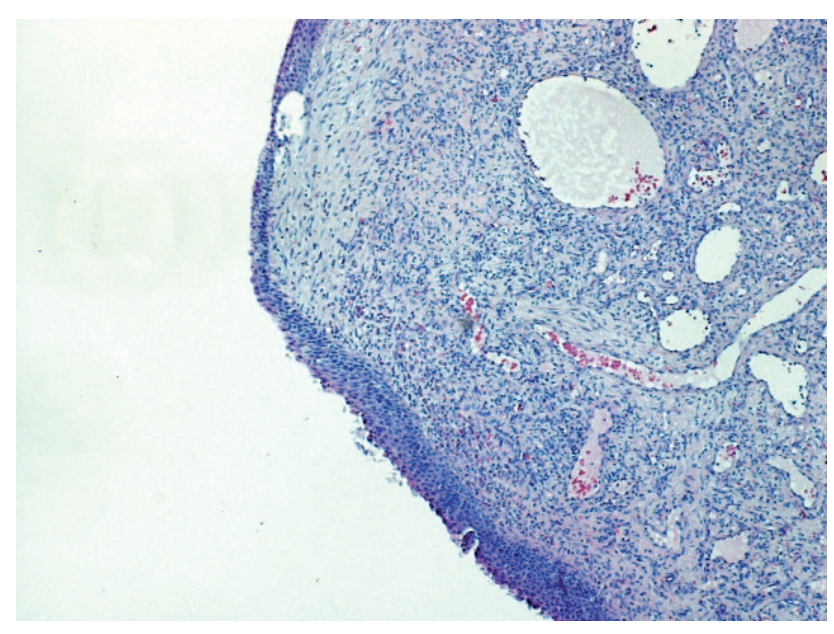

Fig. 2: Numerous irregular blood vessels ranging from capillaries and sinusoids to large vessels, lying in a fibrous stroma. Metaplastic squamous epithelium with respiratory epithelium remnants was present on the tumor surface $($ H\&E stain; $\times 100)$. 
Tab. 1: Cases of nasal cavity angiofibroma reported in the world literature, including the data regarding treatment approaches and immunohistochemical analyses. (Abbreviation: IHC - immunohistochemistry)

\begin{tabular}{|c|c|c|c|c|c|c|c|c|}
\hline Case & Reference & Sex/Age & Site & Left/Right & Symptoms & Duration & Therapy & IHC \\
\hline 1. & (5) & $\mathrm{M} / 12$ & \begin{tabular}{|l|} 
Lateral \\
nasal \\
wall
\end{tabular} & Right & Nasal obstruction & 4 months & $\begin{array}{l}\text { Lateral } \\
\text { rhinotomy }\end{array}$ & No \\
\hline 2. & (6) & $\mathrm{M} / 13$ & $\begin{array}{l}\text { Nasal } \\
\text { septum }\end{array}$ & Left & $\begin{array}{l}\text { Nasal obstruction, } \\
\text { epistaxis }\end{array}$ & 2 months & $\begin{array}{l}\text { Transnasal } \\
\text { excision }\end{array}$ & No \\
\hline 3. & (7) & $\mathrm{M} / 9$ & $\begin{array}{l}\text { Nasal } \\
\text { septum }\end{array}$ & Right & $\begin{array}{l}\text { Nasal obstruction, } \\
\text { epistaxis }\end{array}$ & 1.5 months & $\begin{array}{l}\text { Transnasal } \\
\text { excision }\end{array}$ & No \\
\hline 4. & (8) & $\mathrm{M} / 62$ & \begin{tabular}{|l} 
Lateral \\
nasal wall
\end{tabular} & Right & $\begin{array}{l}\text { Nasal obstruction, } \\
\text { epistaxis }\end{array}$ & 2 months & $\begin{array}{l}\text { Transnasal } \\
\text { excision }\end{array}$ & No \\
\hline 5. & (9) & $\mathrm{M} / 71$ & $\begin{array}{l}\text { Lateral } \\
\text { nasal wall }\end{array}$ & Right & Epistaxis & 3 months & $\begin{array}{l}\text { Lateral } \\
\text { rhinotomy }\end{array}$ & No \\
\hline 6. & (10) & $\mathrm{F} / 69$ & $\begin{array}{l}\text { Nasal } \\
\text { vault }\end{array}$ & Left & Nasal obstruction & 3 months & $\begin{array}{l}\text { Open } \\
\text { rhinoplasty }\end{array}$ & Yes/actin, vimentin \\
\hline 7. & (11) & $\mathrm{M} / 42$ & $\begin{array}{l}\text { Nasal } \\
\text { septum }\end{array}$ & Left & $\begin{array}{l}\text { Nasal obstruction, } \\
\text { epistaxis }\end{array}$ & 4 months & $\begin{array}{l}\text { Transnasal } \\
\text { excision }\end{array}$ & No \\
\hline 8. & (12) & $\mathrm{F} / 78$ & $\begin{array}{l}\text { Inferior } \\
\text { turbinate }\end{array}$ & Right & $\begin{array}{l}\text { Nasal obstruction, } \\
\text { epistaxis }\end{array}$ & 2 months & $\begin{array}{l}\text { Transnasal } \\
\text { excision }\end{array}$ & No \\
\hline 9. & (13) & $\mathrm{M} / 9$ & $\begin{array}{l}\text { Inferior } \\
\text { turbinate }\end{array}$ & Left & $\begin{array}{l}\text { Nasal obstruction, } \\
\text { epistaxis }\end{array}$ & 4 months & $\begin{array}{l}\text { Lateral } \\
\text { rhinotomy }\end{array}$ & Yes/actin, CD34 \\
\hline 10. & (14) & $\mathrm{F} / 31$ & $\begin{array}{l}\text { Middle } \\
\text { turbinate }\end{array}$ & Right & Epistaxis & "weeks" & $\begin{array}{l}\text { Midfacial } \\
\text { degloving }\end{array}$ & Yes/actin, vimentin \\
\hline 11. & (15) & $\mathrm{M} / 32$ & $\begin{array}{l}\text { Nasal } \\
\text { septum }\end{array}$ & Right & $\begin{array}{l}\text { Nasal obstruction, } \\
\text { epistaxis }\end{array}$ & 5 months & $\begin{array}{l}\text { Transnasal } \\
\text { excision }\end{array}$ & No \\
\hline 12. & (16) & $\mathrm{M} / 14$ & $\begin{array}{l}\text { Middle } \\
\text { turbinate }\end{array}$ & Right & $\begin{array}{l}\text { Nasal obstruction, } \\
\text { epistaxis }\end{array}$ & 3 months & $\begin{array}{l}\text { Lateral } \\
\text { rhinotomy, } \\
\text { partial } \\
\text { maxillectomy }\end{array}$ & $\begin{array}{l}\text { Yes/actin, } \\
\text { vimentin, CD34 }\end{array}$ \\
\hline 13. & (17) & $\mathrm{M} / 8$ & $\begin{array}{l}\text { Nasal } \\
\text { septum }\end{array}$ & Left & $\begin{array}{l}\text { Nasal obstruction, } \\
\text { epistaxis }\end{array}$ & 5 months & $\begin{array}{l}\text { Lateral } \\
\text { rhinotomy, } \\
\text { transnasal } \\
\text { excision } \\
\end{array}$ & No \\
\hline 14. & (18) & $\mathrm{M} / 17$ & $\begin{array}{l}\text { Lateral } \\
\text { nasal wall }\end{array}$ & Right & Epistaxis & 3 months & $\begin{array}{l}\text { Transnasal } \\
\text { excision }\end{array}$ & No \\
\hline 15. & (19) & $\mathrm{F} / 50$ & $\begin{array}{l}\text { Nasal } \\
\text { septum }\end{array}$ & Right & $\begin{array}{l}\text { Nasal obstruction, } \\
\text { epistaxis }\end{array}$ & 24 months & $\begin{array}{l}\text { Transnasal } \\
\text { excision }\end{array}$ & No \\
\hline 16. & (19) & $\mathrm{F} / 34$ & $\begin{array}{l}\text { Nasal } \\
\text { septum }\end{array}$ & Left & $\begin{array}{l}\text { Nasal obstruction, } \\
\text { epistaxis }\end{array}$ & 12 months & $\begin{array}{l}\text { Transnasal } \\
\text { excision }\end{array}$ & No \\
\hline 17. & $(20)$ & $\mathrm{M} / 30$ & $\begin{array}{l}\text { Inferior } \\
\text { turbinate }\end{array}$ & Right & Nasal obstruction & 6 months & $\begin{array}{l}\text { Transnasal } \\
\text { excision }\end{array}$ & No \\
\hline 18. & $(21)$ & $\mathrm{F} / 60$ & $\begin{array}{l}\text { Inferior } \\
\text { turbinate }\end{array}$ & Right & $\begin{array}{l}\text { Nasal obstruction, } \\
\text { epistaxis }\end{array}$ & 3 months & $\begin{array}{l}\text { Transnasal } \\
\text { excision }\end{array}$ & No \\
\hline 19. & $(22)$ & $\mathrm{M} / 33$ & $\begin{array}{l}\text { Inferior } \\
\text { turbinate }\end{array}$ & Left & $\begin{array}{l}\text { Nasal obstruction, } \\
\text { progressive } \\
\text { swelling of the } \\
\text { nose }\end{array}$ & 3 months & $\begin{array}{l}\text { Lateral } \\
\text { rhinotomy }\end{array}$ & No \\
\hline 20. & $(22)$ & $\mathrm{M} / 60$ & $\begin{array}{l}\text { Inferior } \\
\text { turbinate }\end{array}$ & Right & Nasal obstruction & 12 months & $\begin{array}{l}\text { Transnasal } \\
\text { excision }\end{array}$ & No \\
\hline 21. & (23) & $\mathrm{M} / 27$ & $\begin{array}{l}\text { Nasal } \\
\text { septum }\end{array}$ & Right & $\begin{array}{l}\text { Nasal obstruction, } \\
\text { epistaxis }\end{array}$ & "years" & $\begin{array}{l}\text { Lateral } \\
\text { rhinotomy }\end{array}$ & Yes/actin, CD34 \\
\hline
\end{tabular}




\begin{tabular}{|c|c|c|c|c|c|c|c|c|}
\hline Case & Reference & Sex/Age & Site & Left/Right & Symptoms & Duration & Therapy & IHC \\
\hline 22. & (24) & $\mathrm{M} / 9$ & $\begin{array}{l}\text { Nasal } \\
\text { septum }\end{array}$ & Left & $\begin{array}{l}\text { Nasal obstruction, } \\
\text { epistaxis }\end{array}$ & "months" & $\begin{array}{l}\text { Transnasal } \\
\text { excision }\end{array}$ & No \\
\hline 23. & $(25)$ & $\mathrm{M} / 62$ & $\begin{array}{l}\text { Inferior } \\
\text { turbinate }\end{array}$ & Left & $\begin{array}{l}\text { Nasal obstruction, } \\
\text { epistaxis }\end{array}$ & 2 months & $\begin{array}{l}\text { Open } \\
\text { approach } \\
\text { (Denker) }\end{array}$ & Yes/CD34 \\
\hline 24. & (26) & $\mathrm{F} / 57$ & $\begin{array}{l}\text { Nasal } \\
\text { septum }\end{array}$ & Right & Nasal obstruction & 12 months & $\begin{array}{l}\text { Transnasal } \\
\text { excision }\end{array}$ & No \\
\hline 25. & (27) & $\mathrm{F} / 63$ & $\begin{array}{l}\text { Middle } \\
\text { turbinate }\end{array}$ & Left & $\begin{array}{l}\text { Nasal obstruction, } \\
\text { epistaxis }\end{array}$ & 8 months & $\begin{array}{l}\text { Transnasal } \\
\text { excision }\end{array}$ & $\begin{array}{l}\text { Yes/actin, desmin, } \\
\text { vimentin, f. VIII, } \\
\text { CD31, CD34 }\end{array}$ \\
\hline 26. & (28) & $\mathrm{M} / 19$ & $\begin{array}{l}\text { Nasal } \\
\text { septum }\end{array}$ & Left & $\begin{array}{l}\text { Nasal obstruction, } \\
\text { epistaxis }\end{array}$ & 6 months & $\begin{array}{l}\text { Transnasal } \\
\text { excision }\end{array}$ & $\begin{array}{l}\text { Yes/CD31, } \\
\text { vimentin, factor } \\
\text { XIIIa }\end{array}$ \\
\hline 27. & (29) & $\mathrm{M} / 22$ & $\begin{array}{l}\text { Nasal } \\
\text { septum }\end{array}$ & Left & Nasal obstruction & 3 months & $\begin{array}{l}\text { Transnasal } \\
\text { excision }\end{array}$ & Yes/actin, vimentin \\
\hline 28. & $(30)$ & $\mathrm{M} / 18$ & $\begin{array}{l}\text { Nasal } \\
\text { septum }\end{array}$ & Left & $\begin{array}{l}\text { Nasal obstruction, } \\
\text { epistaxis }\end{array}$ & 3 months & $\begin{array}{l}\text { Transnasal } \\
\text { excision }\end{array}$ & No \\
\hline 29. & $(31)$ & $\mathrm{F} / 57$ & $\begin{array}{l}\text { Inferior } \\
\text { turbinate }\end{array}$ & Left & $\begin{array}{l}\text { Nasal obstruction, } \\
\text { epistaxis }\end{array}$ & 3 months & $\begin{array}{l}\text { Transnasal } \\
\text { excision }\end{array}$ & Yes/actin, CD34 \\
\hline 30. & $(32)$ & $\mathrm{M} / 31$ & $\begin{array}{l}\text { Nasal } \\
\text { septum }\end{array}$ & Left & $\begin{array}{l}\text { Nasal obstruction, } \\
\text { epistaxis }\end{array}$ & 3 months & $\begin{array}{l}\text { Transnasal } \\
\text { excision }\end{array}$ & No \\
\hline 31. & (32) & $\mathrm{M} / 42$ & $\begin{array}{l}\text { Nasal } \\
\text { septum }\end{array}$ & Right & $\begin{array}{l}\text { Nasal obstruction, } \\
\text { epistaxis }\end{array}$ & 4 months & $\begin{array}{l}\text { Transnasal } \\
\text { excision }\end{array}$ & No \\
\hline 32. & (32) & $\mathrm{L} / 18$ & $\begin{array}{l}\text { Nasal } \\
\text { septum }\end{array}$ & Left & $\begin{array}{l}\text { Nasal obstruction, } \\
\text { epistaxis }\end{array}$ & 2 months & $\begin{array}{l}\text { Transnasal } \\
\text { excision }\end{array}$ & No \\
\hline 33. & $(32)$ & $\mathrm{F} / 40$ & $\begin{array}{l}\text { Nasal } \\
\text { septum }\end{array}$ & Right & $\begin{array}{l}\text { Nasal ostruction, } \\
\text { epistaxis }\end{array}$ & 12 months & $\begin{array}{l}\text { Transnasal } \\
\text { excision }\end{array}$ & No \\
\hline 34. & $(32)$ & $\mathrm{M} / 15$ & $\begin{array}{l}\text { Nasal } \\
\text { septum }\end{array}$ & Right & $\begin{array}{l}\text { Nasal obstruction, } \\
\text { epistaxis }\end{array}$ & 3 months & $\begin{array}{l}\text { Transnasal } \\
\text { excision }\end{array}$ & No \\
\hline 35. & $(32)$ & $\mathrm{F} / 47$ & $\begin{array}{l}\text { Nasal } \\
\text { septum }\end{array}$ & Right & $\begin{array}{l}\text { Nasal obstruction, } \\
\text { epistaxis }\end{array}$ & 4 months & $\begin{array}{l}\text { Transnasal } \\
\text { excision }\end{array}$ & No \\
\hline 36. & $(32)$ & $\mathrm{M} / 12$ & $\begin{array}{l}\text { Inferior } \\
\text { turbinate }\end{array}$ & Right & $\begin{array}{l}\text { Nasal obstruction, } \\
\text { epistaxis }\end{array}$ & 1 month & $\begin{array}{l}\text { Transnasal } \\
\text { excision }\end{array}$ & $\begin{array}{l}\text { Yes/CD34, } \\
\text { vimentin }\end{array}$ \\
\hline 37. & (33) & $\mathrm{M} / 60$ & $\begin{array}{l}\text { Nasal } \\
\text { septum }\end{array}$ & Right & Epistaxis & 2 months & $\begin{array}{l}\text { Transnasal } \\
\text { excision }\end{array}$ & $\begin{array}{l}\text { Yes/actin, CD34, } \\
\beta \text {-catenin, CD117 }\end{array}$ \\
\hline 38. & (33) & $\mathrm{M} / 56$ & $\begin{array}{l}\text { Nasal } \\
\text { septum }\end{array}$ & Right & Nasal obstruction & 3 months & $\begin{array}{l}\text { Transnasal } \\
\text { excision }\end{array}$ & $\begin{array}{l}\text { Yes/actin, CD34, } \\
\beta \text {-catenin, CD117 }\end{array}$ \\
\hline 39. & (34) & $\mathrm{M} / 19$ & $\begin{array}{l}\text { Nasal } \\
\text { septum }\end{array}$ & Right & $\begin{array}{l}\text { Nasal obstruction, } \\
\text { epistaxis }\end{array}$ & 1 month & $\begin{array}{l}\text { Transnasal } \\
\text { excision }\end{array}$ & No \\
\hline
\end{tabular}

maxillary sinus (Fig. 1). We attempted to undertake biopsy in topical anaesthesia and we excided a bigger part of the lesion. It was lobular, purple colored, about $15 \mathrm{~mm}$ long tumor, with the diameter up to $9 \mathrm{~mm}$. This was followed by profuse bleeding which was controlled with anterior nasal packing. The patient then underwent endoscopic endonasal examination, under general anaesthesia. We found a small lobular lesion pedunculated to the anterior part of the left middle turbinate. It had a thin pedicle which was bleeding intensively. After we resected the anterior third of the middle turbinate together with tumour, the bleeding significantly decreased. After that, the anterior ethmoidectomy, middle and inferior meatal antrostomy were performed for excision of hyperplastic mucosa and evacuation of secretions from the maxillary and ethmoid sinus. The antibiotic oral therapy (amoxicillin-clavulanate, $1000 \mathrm{mg}$, two times for a day) was used for ten days. The anterior nasal packing was removed on the fifth postoperative day and rhinoscopic finding seemed good. Five years later, the patient was free of symptoms. There was no local rhinoscopic and CT evidence of recurrence after five years of follow-up.

\section{Pathohistological and immunohistochemical analysis}

After the surgical excision, the tissue was fixed in $10 \%$ formaldehide, routinely processed and embedded in paraffin vax. Consecutive sections, $4 \mu \mathrm{m}$ in thickness, were 
stained with haematoxylin and eosin. Histopathological examination of the excised masses (Hematoxylin-Eosin stain) showed a metaplastic squamous epithelium with the respiratory epithelium remnants on the tumour surface. Under the epithelium, we found many irregular blood vessels range from capillaries and sinusoids to large vessels, lined with one layer of flat endothelial cells lying in a fibrous stroma (Fig. 2). Several fields of proliferate fibrosis were seen. This suggested the diagnosis of angiofibroma.

For immunohistochemical analysis, the avidin-biotin peroxidase technique was performed. All vascular cells were positive for CD34 (Fig. 3a). Endothelium in small blood vessels (capillaries and sinusoids) was positive for CD31 (Fig. 3b). Most of endothelial cells were positive for factor VIII (Fig. 3c). Therefore, the finding was positive for $\alpha$-actin. In thick smooth muscle layers, the orientation of muscle cells is frequently disturbed. Frequently, individual cells differ in size and shape. The muscle layers disperse peripherally into individual cells and create the impression of vessel-independent smooth muscle cells within the stroma (Fig. 3d). We found a negative raction for smooth muscle desmin, and a positive reaction for stromal cells vimentin. Thus, immunohistochemical analysis confirmed the diagnosis of angiofibroma.

\section{Discussion}

Angiofibroma is a unique fibrovascular tumor with the specific pathohistological finding of irregularly configured, endothelial lined vascular spaces embedded in
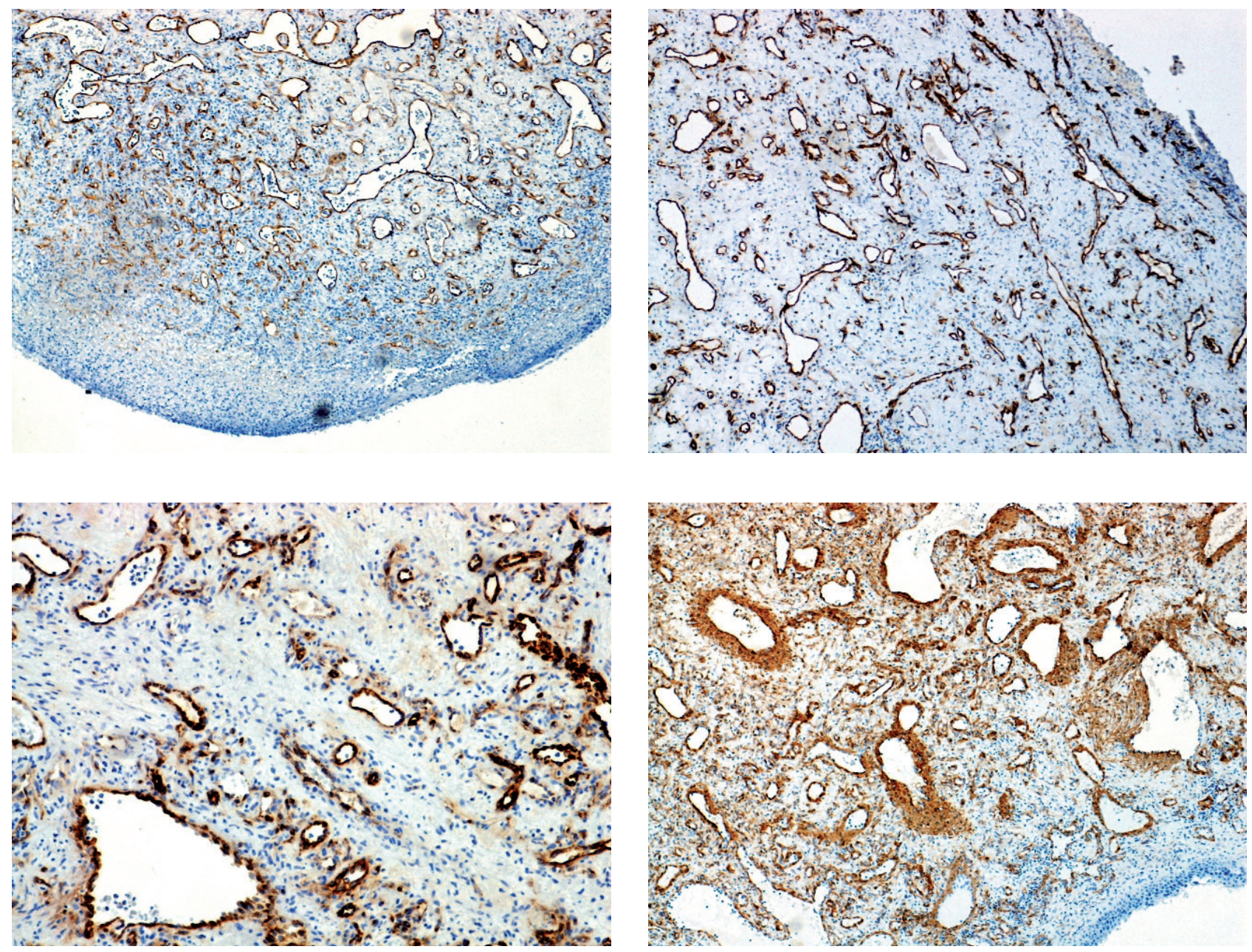

Fig. 3: Immunohistochemical analysis of excised mass:

(a) All endothelial cells were positive for CD34 (original magnification $\times 100$ );

(b) Small blood vessels (capillaries and sinusoids) were positive for CD31 (original magnification $\times 100$ );

(c) Most of endothelial cells were positive for factor VIII (original magnification $\times 200$ );

(d) Irregularity of the smooth muscle layers: occasionally, the muscle layers disperse peripherally into individual cells (immunohistochemistry for $\alpha$-actin; original magnification $\times 200$ ). 
a fibrous stroma. In the world literature, angiofibromas have been described alternatively as a hemangioma, vascular malformation, overgrowth of paraganglionic tissue, hamartoma, or extracolonic manifestation of familial adenomatous polyposis $(3,35,36,37)$. Many hypotheses have been proposed to explain the etiology of this lesion, but none of them found general acceptance. Of these hypotheses, vascular malformation and hemangioma are the most frequent topics of debate. The current one, which presents angiofibroma as a vascular malformation, arose from the observation of discontinuous vascular basal laminae, focal lack of pericytes and pronounced irregularity of the smooth muscle layers (3). In accordance with these histopathological findings, the embryological explanation for the formation of this vascular malformation is an incomplete regression of the first branchial arch artery (3). The results of an immunohistochemical study conducted by Starlinger et al. (38) confirmed the vide range of vascular architecture in "juvenile" angiofibroma. High level of laminin $\alpha 2$ expression in angiofibroma vessels is suggested to indicate presence of vessels of early developmental stage of this tumor, supporting the concept that plexus remnants of the first branchial arch artery contribute to the vascular tumor component (38).

On the other hand, uncontrolled endothelial cell autostimulation and proliferation is the hallmark of hemangiomas. However, vascular malformations do not exhibit these pathological findings. Uncontrolled endothelial proliferation is the major vascular birthmark of separating the classification of hemangioma from different types of vascular malformations. Takahashi et al. (39) found that vascular endothelial growth factor (VEGF) expression was elevated in the tissue of human hemangiomas. In contrast, vascular malformations did not express VEGF. These data demonstrate differences in cell markers between proliferating hemangiomas and vascular malformations, which reflect the biological distinctions between these vascular lasions. Zhang et al. (40) studied immunostaining of VEGF and CD34 in tissue of angiofibromas and in orbital cavernous hemangioma. CD34 marker has been described as a useful diagnostic marker of vascular tumors. Beham et al. (41) studied the expression of CD34 in juvenile nasopharyngeal angiofibromas and confirmed that there was an exclusive staining of endothelial cells, while stromal fibroblasts and smooth muscle cells were not reactive. They concluded that angiofibroma is a vasoproliferative malformation. Zhang et al. (40) found high level of immunoreactivity for CD34 in both angiofibroma and cavernous hemangioma. However, the CD34 immunoexpression was significantly higher in angiofibromas than that in cavernous hemangioma (40). This suggested that angiofibromas have different histogenetic nature than vascular malformations and hemangiomas.

The predilection of angiofibromas for adolescent males suggests a relationship with sex hormones. Hormonal receptors have been observed in the tumor tissue (42). Hormonal hypothesis suggests that high estrogen levels protect females. This could explain the male predominance and the small number of reported female cases. It has been hypothesized that angiofibroma is a testosterone-dependent tumor that arises from a fibrovascular nidus in the nasopharynx that lies dormant until the onset of puberty (42). After that, the tumor grows and becomes symptomatic.

Do extranasopharyngeal angiofibromas of the nasal cavity have different clinical and pathological characteristics in comparisson to nasopharyngeal ones? Windfuhr and Remmert (43) summarized a total of 65 patients with extranasopharyngeal angiofibromas. The most common site of origin is the maxillary sinus, followed by ethmoidal labyrinth. On the other hand, our review showed that the most common primary location of nasal angiofibroma is the nasal septum, followed by inferior and middle turbinate (5-34). Brunner (44) proposed that angiofibromas originate in the periosteum of the anterior margin of the atlas at the lower surface of the sphenoid bone, which is called fascia basalis. During its developpment, this tissue extends up to the posterior part of the vomer and ethmoid bone (44). Akbas and Anadolu (19) suggested that extension of fascia basalis anteriorly, as a developmental anomaly, results in formation of small islands of ectopic tissue. These small ectopic tissues could be the sites of origin of nasal septal angiofibromas. As middle turbinate is a part of ethmoid bone, we supposed that the fascia basalis remnants maybe existed in the middle turbinate region. This could be an explanation for pathogenesis of angiofibromas originating from the middle concha. However, primary localization of angiofibroma in the region of inferior turbinate, which is not the part of ethmoid bone, is difficult to explain.

In contrast to nasopharyngeal angiofibromas, which were sporadically reported in female patients, nasal cavity angiofibromas occur in females in $30.76 \%$ cases. In nasopharyngeal angiofibromas, the patients are 6 to 26 years old with an average age of 15.9 years (45). The oldest patient with nasal angiofibroma being 78 years old, and the youngest one being 8 years of age. The mean age was 36.10 years. Nasopharyngeal angiofibromas, localized in the nasopharynx and posterior in the lateral wall of the nose, have symptoms like nasal congestion, anosmia, recurrent epistaxis, secretion and malfunction of the Eustachian tube with middle ear effusion or orbital complications. Unlike this, the patients with nasal cavity angiofibromas have unilateral nasal obstruction and epistaxis as dominant symptoms. The clinical presentation is usually earlier than in the cases of nasopharyngeal tumors because of limited space of the nasal cavity. Anterior rhinoscopy and/or nasal endoscopy revealed the polypoid or fleshy masses with a smooth or ulcerative surface filling the nasal cavity. Imaging modalities such as CT and MRI may provide information regarding the extension of the lesion. Angiofibroma is characterized by typical radiological findings. Tumor extension and blood supply can be accurately determined by CT, MRI, angio-MRI, and angiography to select the least traumatic approach with secure haemostatic control and maximum 
preservation of the anatomy responsible for facial growth (46). CT basically provides the bony landmarks for the surgery, whereas MRI displaying a homogenous contrast enhancement, helps in differentiating tumor from chronic sinusitis secondary to the blockage of affected paranasal sinuses (46). Moreover, it easily delineates potential intracranial extension and offers an ideal method for follow-up without irradiation (46). Additional angio-MRI provides a picture of the vascular supply avoiding a diagnostic angiography (46). Depending on the material employed for the angiography, embolisation can be performed 24-48 hours before surgery. The vascular supply comes mainly from the internal maxillary artery and the ascending pharyngeal artery (47). Branches originating as neovascularization from the internal carotid artery are rare in extracranial tumors, but can be observed when the cavernous sinus is involved (48). These new vessels can be embolized, but with a higher risk of complications. Alternatively, direct intratumoral embolisation under general anesthesia has been proposed for such cases (48). Embolisation provides a $60-70 \%$ reduction of the intraoperative bleeding and the need for blood transfusions (49). Direct intraoperative identification and ligation or coagulation of the major supplying vessels, with the help of a hypotensive general anesthesia, can be an alternative to the embolisation in both smaller and higher staged tumors (49). Various modalities have been used for treatment of nasopharyngeal angiofibromas, including surgery, hormonal therapy, irradiation and systemic chemotherapy (50). However, surgery remains the primary course of treatment. The surgical approach is determined by the size, location and blood supply of the tumor and surgical procedures include transpalatal techniques, lateral rhinotomy, midfacial degloving, infratemporal approaches, and combined infratemporal and frontotemporal techniques $(51,52)$. The evolution of endoscopic sinus surgery allows for minimally invasive procedures with low morbidity and complications only in cases of nasal angiofibromas $(51,52)$. In most cases of angiofibroma arising from the nasal cavity, location and dimension of tumors permitted surgeons to remove the tumors completely, using wide endoscopic excision, without previous selective arteriography and embolization. In general, the prognosis of nasopharyngeal angiofibromas is good, although the recurrence rates of 50-61\% have been reported (52). Vascularity, age of onset, duration of symptoms, the site of attachment of the tumor, and extension of angiofibromas are factors influencing the recurrence (52). Complications of the endoscopic approach can be rated as similar to a total spheno-ethmoidectomy. A loss of tearing causing a dry eye has been specifically related to endonasal removal of angiofibromas, most probably due to damage to branches of the sphenopalatine ganglion (53). Blood loss during endoscopic removal is variable. Nicolai et al. (54) found that the amount of blood loss is strongly linked to the quality of embolisation and to the tumor volume or extension. Comparing the blood loss between endoscopic and open angiofibroma removal, the mean blood loss seemed to be lower in the endoscopic approaches and in lower staged tumors (55). However, generally, a bias has to be considered: larger tumors were more frequently addressed by an open approach, while lower staged tumors were mainly operated on endoscopically (52). Accordingly, the rate of recurrent tumors does not depend of surgical approach. It is rather low for smaller lesions, increasing in the higher staged tumors (52). Comparison between endoscopic and external approaches is biased because larger tumors have tended to be resected using open-approach operations (52). In contrast to these findings, recurrence was not reported in patients with extranasopharyngeal angiofibromas originating from nasal cavity structures.

Other non-surgical treatment options have been proposed. Radiotherapy is advocated to address recurrent and extensive or intracranial tumors (56). Recent radiotherapy studies report tumor control in $85 \%$ after applying 30-35 Gy in advanced stages (52). However, radiotherapy can produce long-term sequelae in adolescents such as growth impairment, cataracts, basal cell carcinoma of the skin within the radiation field, encephalopathy with dementia, or possibly radiation-induced intracranial tumors (52). Although malignant transformation in angiofibroma after radiotherapy has been reported (57), it has been recommended as an adjuvant therapy for unresectable tumors, failure of complete tumor removal, or for extensive intracranial extension (52). Chemotherapy with doxorubicine and dacarbacine has been proposed for recurrences, although the experience is limited and its used proposed for selected cases with locally aggressive growth (58). Hormonal therapy has not been formerly evaluated yet, despite promising studies. A recent study does not show any positive effect (59).

In our case, we suspected a vascular tumor and decided to remove mass. We did not perform preoperative embolisation because the tumor was small in dimension and at an accessible location. We expected that the bleeding could be easily controlled. With the patient under general anesthesia, the tumor was removed via an endonasal endoscopic approach.

Atypical localization of nasal angiofibromas needs a careful differential diagnosis in relation to other vascular lesions such as lobular capillary hemangioma and sinonasal-type hemangiopericytoma. Precise histopathological examination of specimens suspected to be angiofibroma is necessary for exact diagnosis. Classically, angiofibromas are composed of a dense fibrous stroma with spindled to stellate stromal cells and variably-sized thin-walled vascular spaces, wich are sometimes difficult to appreciate. Hemangiomas generally consist of small amount of fibrous tissue and show lobulation in different degrees (60). Lobular appearance is a very characteristic feature of capillary hemangioma, which is the most seen subtype of hemangiomas in head and neck. This lobulation is also very useful in differential diagnosis of nasal angiofibromas from capillary hemangiomas (60). The most important criterion 
for differential diagnosis of angiofibromas from other vascular tumors is dense stromal fibrosis. Stromal fibrosis is not excessive in hemangiomas and not seen in capillary hemangiomas. Therefore, anastomosing vessel architecture, which is very specific for capillary hemangiomas, is not seen in angiofibromas (60). So, immunohistochemistry is not necessary for differential diagnosis in relation to lobular capillary hemangioma. However, immunohistochemisal analysis may be very helpful for differentiation between angiofibroma and sinonasal-type hemangiopericytoma. Sinonasal-type hemangiopericytoma is a rare vascular tumor, arising from pericytes surrounding capillaries, situated usually in the nasal cavity and paranasal sinuses region, originating in the most cases from nasal septal mucosa (61). An immunohistochemical analysis of this lesion shows positive staining for vimentin, and negative staining for CD34 and smooth muscle $\alpha$-actin. Angiofibromas have positive staining for vimentin, CD34 and $\alpha$-actin. Then, sinonasal-type hemangiopericytoma can be considered to be distinct from angiofibroma of the nasal cavity.

\section{Conclusion}

It should be kept in mind that angiofibromas originate from the extranasopharyngeal regions of the head and neck. Angiofibromas originating from the nasal cavity structures are clinically distinct from nasopharyngeal angiofibromas and can therefore be misdiagnosed. Nasal angiofibromas should be included in the differential diagnosis of vascular lesions of the nasal/paranasal sinuses area, especially from capillary hemangiomas and sinonasal-type hemangiopericytoma. Immunohistochemical analysis is important in all doubtful cases, especially in those with atypical location and may be very helpful in distinction from nasal hemangiopericytomas.

\section{References}

1. Barnes L, Brandwein M, Som PM. Diseases of the nasal cavity, paranasal sinuses and nasopharynx. In: Barnes L, editor. Surgical pathology of the head and neck. New York: Marcel Dekker, 2001, pp. 440-516.

2. Schick B, Veldung B, Wemmert S, et al. P53 and Her-2/neu in juvenile angiofibromas. Oncol Rep 2005; 13: 453-7.

3. Beham A, Beham-Schmid C, Regauer S, Aubock L, Stammberger H. Nasopharyngeal angiofibroma: true neoplasm or vascular malformation? Adv Anat Pathol 2000; 7: 36-46.

4. Schick B, Plinkert PK, Prescher A. Aetiology of angiofibromas: reflection on their specific vascular component. Laryngorhinootologie 2000; 81: 280-4. (in German)

5. Okiabo MN, Jacobs A. An isolated case of juvenile angiofibroma in the nasal cavity. Ear Nose Throat J 1993; 62: 70-4.

6. Hiraide F, Matsubara H. Juvenile nasal angiofibroma: a cese report. Eur Arch Otorhinolaryngol 1984; 239: 235-41.

7. Sarpa JR, Novelly. Extranasopharyngeal angiofibroma. Otolaryngol Head Neck Surg 1989; 101: 693-7.

8. Gudea F, Vega M, Canals E, Montserrat JM, Valdano J. Role of radiation therapy for "juvenile" angiofibroma. J Laryngol Otol 1990; 104: 725-6.

9. Pastor Quirante FA, Perez Martinez F, Diaz Caparros F, Montalban Romero S, Perez Guillermo M. Nasal angiofibroma in an adult. An Otorrinolaringol Ibero Am 1994; 21: 479-86. (in Spanish)

10. Hersh SP, Grimes CD Jr, Harrison WG, Iwamoto T. Angiofibroma of the nasal cavity: a clinical and electron microscopic study. Otolaryngol Head Neck Surg 1995; 112: 603-6.
11. Bhargava SK, Phatak S, Phatak S. Angiofibroma arising from nasal septum in adult male-a rare occurrence. Indian J Otolaryngol Head Neck Surg 1995; 47: 39-41.

12. Alvi A, Myssiorek D, Fuchs A. Extranasopharyngeal angiofibroma. J Otolaryngol 1995; $25: 346-8$

13. Gaffney R, Hui Y, Vojvodich S, Forte V. Extranasopharyngeal angiofibroma of the inferior turbinate. Int J Pediatr Otorhinolaryngol 1997; 40: 177-80.

14. Péloquin L, Klossek JM, Basso-Brusa F, Gougeon JM, Toffel PH, Fontanel JP. A rare case of nasopharyngeal angiofibroma in a pregnant woman. Otolaryngol Head Neck Surg 1997; 117: S111-114.

15. Shah N, Hathiram BT, Dwivedi A, Sheth K, Grewal DS, Behl NK. Nasopharyngeal angiofibroma-an unusual origin and presentation. Indian J Otolaryngol Head Neck Surg 1999; 52: 179-81.

16. Huang RY, Damrose EY, Blackwell KE, Cohen AN, Calcaterra TC. Extranasopharyngeal angiofibroma. Int J Pediatr Otorhinolaryngol 2000; 56: 59-64.

17. Handa KK, Kumar A, Singh MK, Chhabra AH. Extranasopharyngeal angiofibroma arising from the nasal septum. Int J Pediatr Otorhinolaryngol 2001; 58: 163-6.

18. Crespo del Hierro J, Gete Garcia P, Coello Casariego G, Rivas E, Monge Jodra R, Alvarez Vicent JJ. Extranasopharyngeal angiofibroma: report of a new case and review of literature. Acta Otorrinolaringol Esp 2002; 53: 297-301. (in Spanish)

19. Akbas Y, Anadolu Y. Extranasopharyngeal angiofibroma of the head and neck in women. Am J Otolaryngol 2003; 24: 413-6.

20. Taggarshe D, Quraishi MS, Dugar JM. Inferior turbinate angiofibroma: an atypical presentation. Rhinology 2004; 42: 45-7.

21. Marcos Garcia M, Pino Rivero V, Pardo Romero G, Trinidad Ruiz G, Pando Pinto JM, Blasco Huelva A. Nasal angiofibroma in a 60 year-old female. A clinical case and literature review. Acta Otorrinolaringol Esp 2004; 55: 195-7.

22. Celik B, Erisen L, Saraydaroglu O, Coskun H. Atypical angiofibromas: a report of four cases. Int J Pediatr Otorhinolaryngol 2005; 69: 415-21.

23. Somdas MA, Ketenci I, Unlu Y, Canoz O, Guney E. Extranasopharyngeal angiofibroma originating from the nasal septum. Otolaryngol Head Neck Surg 2005; 133: 647 .

24. Castillo MP, Timmons CF, McClay JE. Autoamputation of an extranasopharyngeal angiofibroma of the nasal septum. Int J Pediatr Otorhinolaryngol Extra 2006; 1: $267-70$.

25. Nomura K, Shimomura A, Awataguchi T, Murakami K, Kobayashi T. A case of angiofibroma originating from the inferior nasal turbinate. Auris Nasus Larynx 2006; 33: 191-3

26. Tasca I, Ceroni Compadretti G. Extranasopharyngeal angiofibroma of nasal septum. A controversial entity. Acta Otorhinolaryngol Ital 2008; 28: 312-4.

27. Perić A, Baletić N, Cerović S, Vukomanović-Đurđević B. Middle turbinate angiofibroma in an elderly woman. Vojnosanit Pregl 2009; 66: 583-6.

28. Uyar M, Turanlı M, Pak I, Bakır S, Osma Ü. Extranasopharyngeal angiofibroma originating from the nasal septum: a case report. Kulak Burun Bogaz Ihtis Derg 2009; 19: 41-4.

29. Mohindra S, Grover G, Bal AK. Extranasopharyngeal angiofibroma of the nasal septum: a case report. Ear Nose Throat J 2009; 88: E17-19.

30. Gupta N, Vaid L, Churg N, Singh PP. Extranasopharyngeal angiofibroma from the nasal septum: a case report and a mini review. Clin Rhinol 2010; 3: 169-71.

31. Dong KL, Woo YB, Kyoo-Sang J, Seo-Hee R. Atypical angiofibroma originating from the inferior turbinate. Korean J Otolaryngol Head Neck Surg 2012; 55: $382-5$.

32. Szymańska A, Szymański M, Morshed K, Czekayska-Chehab E, Szczerbo-Trojanowska M. Extranasopharyngeal angiofibroma: clinical and radiological presentation. Eur Arch Otorhinolaryngol 2013; 270: 655-60.

33. Garcia-Rodriguez L, Rudman K, Cogbill CH, Loehrl T, Poetker DM. Nasal septal angiofibroma, a subclass of extranasopharyngeal angiofibroma. Am J Otolaryngol 2012; 33: 473-6.

34. Hamdan AL, Moukarbel RV, Kattan M, Natout M. Angiofibroma of the nasal septum. Middle East J Anesthesiol 2012; 21: 653-5.

35. Liang J, Lianq P. The nature of juvenile nasopharyngeal angiofibroma. Otolaryngol Hed Neck Surg 2000; 123: 475-81.

36. Saylam G, Yücel OT, Sungur A, Önerci M. Proliferation, angiogenesis and hormonal markers in juvenile nasopharyngeal angiofibroma. Int J Pediatr Otorhinolaryngol 2006; 70: 227-34.

37. Coutinho-Camillo CM, Brentani MM, Nagai MA. Genetic malformations in juvenile nasopharyngeal angiofibromas. Head Neck 2008; 30: 390-400.

38. Starlinger V, Wendler O, Gramann M, Schick B. Laminin expression in juvenile angiofibroma indicates vessel's early developmental stage. Acta Otolaryngol 2007; 127: 1310-5.

39. Takahashi K, Mulliken JB, Kozakewich HP, Rogers RA, Folkman J, Ezekowich RA. Cellular markers that distinguish the phases of hemangioma during infancy in chilhood. J Clin Invest 1994; 93: 2357-64.

40. Zhang M, Sun X, Yu H, Hu L, Wang D. Biological distinctions between juvenile nasopharyngeal angiofibroma and vascular malformation: An immunohistochemical study. Acta Histochemica 2011; 113: 626-30.

41. Beham A, Regauer S, Beham-Schmid C, Kainz J, Stammberger H. Expression of CD34-antigen in nasopharyngeal angiofibromas. Int J Pediatr Otorhinolaryngol 1998; 44: 245-50. 
42. Johns ME, MacLeod RM, Cantrell RW. Estrogen receptors in nasopharyngeal angiofibromas. Laryngoscope 1980; 90: 628-34.

43. Windfuhr JP, Remmert S. Extranasopharyngeal angiofibroma: etiology, incidence and management. Acta Otolaryngol 2004; 124: 880-9.

44. Brunner H. Nasopharyngeal fibroma. Ann Otol 1942; 51: 30-65.

45. Lloyd G, Howard D, Phelps P, Chesman A. Juvenile angiofibroma: the lessons of 20 years of modern imaging. J Laryngol Otol 1999; 113: 127-34.

46. Lloyd G, Howard D, Lund VJ, Savy L. Imaging for juvenile angiofibroma. J Laryngol Otol 2000; 114: 727-30.

47. Draf W, Berghaus A. Tumors and pseudotumors ("tumor-like lesions") of the frontal cranial base, originating in the nose, the paranasal sinuses and the nasopharynx (including surgical approach). Eur Arch Otorhinolaryngol Suppl 1993 1: 105-86. (in German)

48. Tranbahuy P, Borsik M, Herman P, Wassef M, Casasko A. Direct intratumora embolisation of juvenile angiofibroma. Am J Otolaryngol 1994; 15: 429-35.

49. Glad H, Vainer B, Buchwald C, Petersen BL, Theilgaard SA, Bonvin P, et al. Juvenile nasopharyngeal angiofibroma in Denmark 1981-2003: diagnosis, incidence, and treatment. Acta Otolaryngol 2007; 127: 292-9.

50. Hodges JM, McDevitt AS, El-Sayed Ali AI, Sebelik ME. Juvenile nasopharyngeal angiofibroma: current treatment modalities and future considerations. Indian J Otolaryngol Head Neck Surg 2010; 62: 326-337.

51. Hofmann T, Bernal-Sprekelsen M, Koele W, Reittner P, Klein E, Stammberger H. Endoscopic resection of juvenile angiofibromas - long-term results. Rhinology 2005; 43: 282-9.

52. Lund VJ, Stammberger H, Nicolai P, Castelnuovo P. European Position Paper on Endoscopic management of Tumours of the Nose, Paranasal Sinuses and Skull Base. Rhinol Suppl 2010; 22: 1-143.
53. Hillel AT, Metzinger RC, Nemechek AJ, Nuss DW. Loss of reflex tearing: an expected consequence of juvenile nasopharyngeal angiofibroma. Otolaryngol Head Neck Surg 2005; 133: 605-10.

54. Nicolai P, Berlucchi M, Tomenzoli D, Cappiello J, Trimarchi M, Maroldi R, et al. Endoscopic surgery for juvenile angiofibroma: when and how. Laryngoscope 2003; 113: 775-82.

55. Borghei P, Baradaranfar MH, Borghei SH, Sokhandon F. Transnasal endoscopic resection of juvenile nasopharyngeal angiofibroma without preoperative embolisation. Ear Nose Throat J 2006; 85: 740-6.

56. Fields JN, Halverson KJ, Devineni VR, Simpson JR, Perez CA. Juvenile nasopharyngeal angifibroma: efficacy of radiation therapy. Radiology 1990; 176 $263-5$.

57. Makek MS, Andrews JC, Fisch U. Malignant transformation of a nasopharyngeal angiofibroma. Laryngoscope 1989; 99(10 Pt 1): 1088-92.

58. Goepfert H, Cangir A, Ayala AG, Eftekhari F. Chemotherapy of locally aggressive head and neck toumors in the paediatric age group. Desmoid fibromatosis and nasopharyngeal angiofibroma. Am J Surg 1982; 144: 437-44.

59. Labra A, Chavolla-Magana R, Lopez-Ugalde A, Alanis-Calderon J, Huerta-Delgado A. Flutamide as a preoperative treatment in juvenile angiofibroma (JA) with intracranial invasion: report of 7 cases. Otolaryngol Head Neck Surg 2004; 130: 466-9.

60. Pilch BZ. Soft tissue pathology of the head and neck. In: Keel SB, Rosenberg AE, editors. Head and Neck Surgical Pathology. Lippincott Williams \& Wilkins, Philadelphia, 2001, pp. 389-430 (Chapter 10).

61. Yokoi H, Arakawa A, Kuribayashi K, Inoshita A, Haruyama T, Ikeda K. An immunohistochemical study of sinonasal hemangiopericytoma. Auris Nasus Larynx 2011; 38: 743-6.

Received: 05/07/2013

Accepted in revised form: $21 / 11 / 2013$

\section{Corresponding author:}

Aleksandar Perić, MD, PhD; Department of Otorhinolaryngology, Rhinology Unit,Faculty of Medicine, Military Medical Academy, Crnotravska 17, 11040 Belgrade, Serbia; e-mail: alexneta@sezampro.rs 